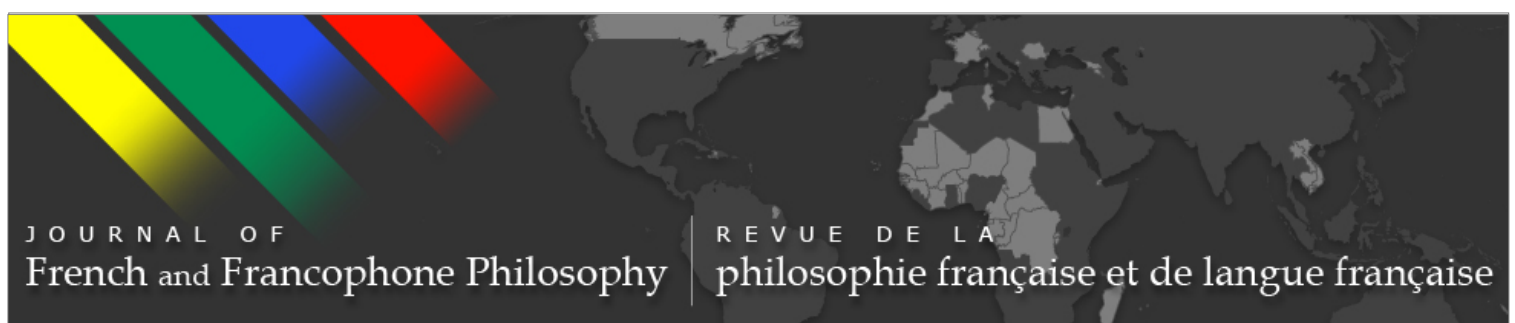

\title{
The Hidden Source of Hermeneutics
}

The Art of Reading in Hugh of St. Victor

\author{
Emmanuel Falque
}

Journal of French and Francophone Philosophy - Revue de la philosophie française et de langue française, Vol XXV, No 1 (2017) pp 121-131.

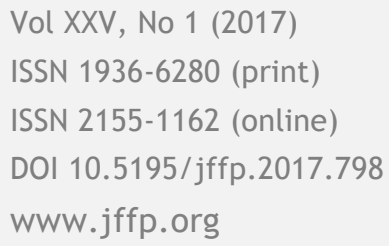

\section{(oc) EY-NG-ND}

This work is licensed under a Creative Commons Attribution-Noncommercial-No Derivative Works 3.0 United States License.

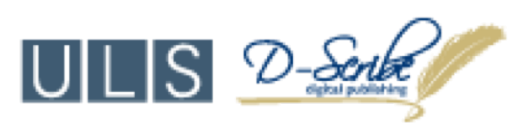

This journal is operated by the University Library System of the University of Pittsburgh as part of its D-Scribe Digital Publishing Program, and is co-sponsored by the University of Pittsburgh Press 


\title{
The Hidden Source of Hermeneutics
}

The Art of Reading in Hugh of St. Victor

\author{
Emmanuel Falque
}

Institut Catholique Paris

It might be surprising to find in a text on hermeneutics that is mostly about Hugh of St. Victor (1096-1141). The hermeneutic question, however, did not begin only yesterday. While this question has its actual sources in Origen (concerning the meaning of Scripture) and Saint Augustine (the firmament of Scripture), it is in the Didascalicon or The Art of Reading by Hugh of St. Victor that it first finds its clearest formulation and its most methodical development. This "hidden source of hermeneutics" allows for a questioning of the foundations of the hermeneutics of the text from its outset (in weighing the short route versus the long route), and also for a return of hermeneutics, or better to turn it, to its primordial origin: a hermeneutics of the "world" or of "creation" [liber mundi], rather than of the "text" and of "Scripture" [liber Scripturae]. A "Catholic" hermeneutics of "the body and the voice" should, in my opinion, take the place of the "Protestant" hermeneutics of "the meaning of the text" (Ricœur) and the "Jewish" hermeneutics of the "body of the letter" (Levinas). This thesis, which is stated and developed in my book Crossing the Rubicon, has its roots and justification in this historical essay on Hugh of St. Victor. Because no contemporary debate can be separated from tradition, it is fitting to draw this lesson once again, even if it will lead us to other lands that were previously repressed.

\section{Introduction: Reading and Living}

"Read and love [legite ergo atque diligite]; and what you read by love, read it for love [et quod propter dilectionem legitis, ad hoc legite ut diligatis]." ${ }_{2}$ This admonition from the prologue of Hugh of St. Victor's In Praise of Charity ought to appear in the frontispiece of every work, if it is the case that there are no other criteria for reading than its fecundity and no point of deciphering the signs on the page unless they illuminate at the same time

Journal of French and Francophone Philosophy | Revue de la philosophie française et de langue française Vol XXV, No 1 (2017) | www.jffp.org | DOI 10.5195/jffp.2017.798 
the enigma of our life. But there is more, and better, to be found in the Victorine, and in this $12^{\text {th }}$ century Renaissance, than a mere statement of principle. Certainly, the imperative to "read" [legere], to "choose" [e-ligere], and even "to love" in reading [di-ligere], is not new in the medieval era. Saint Augustine insists on this in the famous book XIII of his Confessions, which is the basis for all subsequent hermeneutical analyses: "Angels read [legunt], choose [eligunt], and love [diligent]," says the doctor of Hippo in a famous play on words, "They read constantly [semper legunt] and never pass over what they read." ${ }_{3}$ But what is true in the "firmament of writing" - to use the title of Isabelle Bochet's book that is based on Augustine's formula [firmamentum ergo Scriptura Dei est] - is even more true for our simple lives, according to Hugh of St. Victor. The reader does not live, or does not only live, in the firmament of the heavens, like the angels, but turns the concreteness of the world into the most ordinary site of reading. Sacred Scripture, to be sure, is something to be read, but so too are hunting, fishing, the farming of wool or the art of cooking, according to Hugh of Saint Victor's Didascalicon. Here reading is elevated to an "art" - ars legendi - which concerns precisely all of the "arts", including the practical as well as the mechanical arts. ${ }^{5}$

Here we will no longer simply be satisfied with what "ought to be read" (erudition), nor with "the transformation of the reader by the text" (textual hermeneutics), instead we will turn reading itself into the mode of being of our most ordinary existence by extending it to the entirety of the human relation to the world (hermeneutics of facticity or descriptive phenomenology). Everyone will learn how to read in medieval times, but not through a process of alphabetization that only began much later, instead a few (the learned monks or theologians) will teach everyone (lay monks and laity) what it means to "exist in reading": to interpret the world on the model of the reading of Scripture, even though not everyone would know how to decipher the text. The Sacra Scriptura remains the basis of monastic or patristic reading [lectio divina] - "Scripture grows with its readings" [Scriptura cum legentibus crescit] according to Gregory the Great's beautiful saying in his Homilies on Ezekiel. ${ }^{6}$ The method of reading which is attributed to readers is extended to the whole world by Hugh of St. Victor, such that the "art of reading" (ars legendi in the Didascalicon]) becomes at the same time an "art of living" (ars vivendi in the De formatio novitiorum), and thus refers to the most ordinary way of life. In this respect, the most contemporary investigations into the status of the "hermeneutic of the text" could not be further removed from what happened with the Victorines. Here, more than anywhere else, the art of reading [ars legendi] is not or is not only related to a text (whose primary reference still remains the Sacra Scriptura among the Church fathers), instead it relates to life and the world [ars vivendi] in such a way that only a "hermeneutics of facticity" will be able to retain and describe today. Saint Augustine or Origen, as the essential sources of Ricoeur's hermeneutics, will thus be distinguished from Hugh of St. Victor who is the

Journal of French and Francophone Philosophy | Revue de la philosophie française et de langue française

Vol XXV, No 1 (2017) | http://www.jffp.org | DOI 10.5195/jffp.2017.798 
springboard for a hermeneutics of facticity that is closer to "mute and silent experience" or to the "lifeworld" which is such a large part of "descriptive phenomenology."

\section{The Art of Reading and Hermeneutics}

Through this audacious "art of reading" [De studio legendi] or Didascalicon in Hugh of St. Victor, the entire relation between the "text" and the "experience of the text", or better, of hermeneutics and phenomenology, comes to be transformed. In light of Hugh's corpus, we can call into question Ricoeur's decision in The Conflict of Interpretations to "graft hermeneutics onto phenomenology" and his "choice of the long route" over the "short route." Without repeating a debate that has already been sketched out elsewhere, $r$ it should at least be noted that the famous French hermeneut probably took a route that was necessary in his time when there was a legitimate rediscovery of the role of the human sciences in philosophy (1969), but which is no longer the case today:

Instead of asking: on what condition can a knowing subject understand a text or history? one [Husserl and Heidegger] asks: what kind of being is it whose being consists of understanding? [...] Before saying why I propose to follow a more roundabout, more arduous path starting with linguistic and semantic considerations, I wish to do full justice to this ontology of understanding, [...] substituting, for the short route of the Analytic of Dasein, the long route which begins by analyses of language.

Language is indeed important, and even essential in a philosophical perspective that wants to take linguistics into account and turns the "text alone", or "only Scripture" [sola scriptura], into the springboard for religious exegesis.

But in both cases, from a philosophical as well as a theological point of view, Ricoeur's decision is not self-evident. Philosophically, first of all, in that "phenomenology and hermeneutics remain, as much in their origin as in their relatively recent autonomisation, more disjointed than jointed . . . hermeneutics, working on texts, especially the sacred texts, seems almost always secondary in relation to phenomenology which has linked itself in part to a renewed radical methodology.". And theologically, it is not selfevident because in Catholicism the text is less the book of Scripture [liber Scripturae], as is the case with Protestantism or an overly unilateral reading of the Church fathers, than the "book of the world" [liber mundi], or even the "book of life" [liber vitae] or the "book of the body" [liber corporis], for which the Scriptural text only serves here as a go-between. What is primary for the medievals is the world [mundus] and not the text [scriptura]. This is not an argument against the text, but in favor of the view that the true and original

Journal of French and Francophone Philosophy | Revue de la philosophie française et de langue française Vol XXV, No 1 (2017) | http://www.jffp.org | DOI 10.5195/jffp.2017.798 
reading is the reading of the world rather than of Scripture and of humans in Eden rather than of angels in the heavens: "when humans fell and lost their knowledge," says St. Bonaventure in a famous passage from the Hexaemeron, "there was no longer anyone to lead them back to God, [...] this book [iste liber], that is, the world [scilicet mundus], was then as it were dead and defaced. Therefore another book [alius liber] was necessary, by which humans would be illumined in order to be able to interpret the metaphors of things [metaphoras rerum]. This book is Scripture [autem liber est Scripturae]."10

The question then, and again today, remains, or rather, the suspicion already formulated here or there remains, but this time it is rooted in a Victorine hermeneutics and its specific attention to the "book of life" [liber vitae] rather than "the book of Scripture" [liber Scripturae]. As I have asked elsewhere, does not "the excessive attention to the support or mediation sometimes kill that which it supports or conveys: the often inexpressible meaning of experience, which it still seeks to describe?" ${ }_{11}$ For the "hermeneutics of the text" and the "long route" (Ricoeur), I will substitute a "hermeneutics of the body" (Husserl, Merleau-Ponty) or of "facticity" (Heidegger), as its most direct and most necessary "short route". Far from denying the hermeneutic meaning of the text, this enterprise will show instead that a "life world" or an "ontology of understanding" always stands more originally on this side of the deciphering of language - the latter means nothing if it does not rejoin the "original lived experience" of the text itself and if it does not aim for the transformation of the reader by the text.

\section{Learning to Read}

To return to the Victorines, and paradoxically support the thesis that the reflective consideration of the "book" in Hugh of St. Victor [De studio legendi] is interested less in the "book" than in "how we read it", is thus to accept that reading appears in this renascent Middle Age not as a "mode of the text" but as a "function of life," not as a consideration of the "parchment of Scripture" but as the consideration of the "deciphering of creatures." Hugh of St. Victor wrote the following superb lines which were reiterated fully later by St. Bonaventure: "this whole sensible world [mundus iste sensibilis] is a kind of book written by the finger of God [quasi quidam liber est scriptus digito Dei] ... and each creature is a kind of figure [quasi figurae], not invented by human determination, but established by the divine will to manifest and in some way signify the invisible wisdom of God [ad manifestandam invisibilium Dei sapietentiam]." and what is nearly rediscovered by Hugh of St. Victor. But if He writes, God does not write texts, and this is what accounts for the originality of Christianity, as well as Judaism, in comparison with Islam, for example, in the writing of the Koran. Rather than writing "texts", God writes with a "gesture", and with his "creative finger", turns this "sensible world" into a

Journal of French and Francophone Philosophy | Revue de la philosophie française et de langue française

Vol XXV, No 1 (2017) | http://www.jffp.org | DOI 10.5195/jffp.2017.798 
"book" whose creatures exist as the "signs" or "figures" who manifest His splendor. Put otherwise, we are the letters or the graphics on the parchment of the world, which it is also up to humans to become able to decipher. Medieval culture is indeed a "passionate culture of reading", as Jean Decorte rightly notes, but not in the sense that "books are present everywhere in great numbers and read assiduously (books are expensive and rare, and the majority of men are illiterate) [...], but only in that people do not read books, but reality itself." ${ }_{13}$ More numerous and more widespread than in the Patristic era, books contain an "art" (of reading) in the 12th century that cannot be ignored. But less multiplied and copied than in the Scholastic and Renaissance eras, they retain their secret of an "art" to be conveyed in its modality ("reading the world") even when it cannot be practiced in its actuality ("reading a text").

Reading as "deciphering" remains, or better, now seems to be exhibited by Hugh of St. Victor as the exemplary type for every human relation to the world. To live is to decipher, or to make oneself able to recover the sense [sensus] under the letter [littera], the meaning [significatio] behind the text [textus]. But what is to be read is initially neither a text nor a work, but only the world [liber mundi], or better, our own life [liber vitae] - the lay brother or lay friar, who certainly can't read, will learn from the theologian how to read their own lives, even though they would only initially see signs there. "When an unlettered person [illiteratus] sees an open book," continues Hugh implicitly referring here to the lay brother bearing the Psalter without the knowledge or ability to read, he notices the shapes [figuras ascipit] but does not recognize the letters [litteras non cognoscit], so stupid [stultus] and carnal people. . . see on the outside [foris speciem] the beauty in these visible creatures, but they do not understand its meaning (sed intus non sed intellegit ratinonem]." ${ }_{14}$

To be clear, the point of this statement, especially in the eyes of Hugh of St. Victor, is not to deplore the widespread illiteracy of an era that has neither a plan nor the means to teach everyone. Quite the contrary, it is precisely to honor the lay brother and to raise him to the rank of a "reader" even though he cannot read that the Victorine makes reading less a mode of the text than a function of life, accounting for the deciphering of creatures rather than the parchment of the Scriptures. In a society that was more regularized in medieval times than in Patristic times, the fool or the illiterate who cannot read must also, and paradoxically, learn how to read, whatever his condition or his faculties. But here reading, as we have said, is "deciphering", or even "interpreting", whether one is studying in the library, copying manuscripts in the scriptorium, renting out the abbey, or working in the fields. "The individual monk might be a rudis - an unlettered servant or uncouth dullard," as Ivan Illich rightly observes in passing in In the Vineyard of the Text, but "even so, he attends the seven daily assemblies in the choir and, in front of the book, sings the Psalms. They have become part

Journal of French and Francophone Philosophy | Revue de la philosophie française et de langue française Vol XXV, No 1 (2017) | http://www.jffp.org | DOI 10.5195/jffp.2017.798 
of his being, and like the most learned brother, he can mouth them while he watches goats." ${ }_{15}$ To put this otherwise, Dom Jean Leclercq quotes an anonymous Marian copy from the 12th century: "a monastery monk is like the Samaritan's beast in his barn: for the one we put hay in his barn; the other mouths diligently and feeds on the memory of Jesus Christ."16 Placed between the lectio monastica inherited from the Church fathers and the lectio scolastica deepened by the medievals, the ars legendi or The Didascalicon in Hugh of St. Victor marks not only a transition from the Church fathers to the Middle Ages, but constitutes a unique and exemplary moment in which one learns to read the world by learning how to read texts, but without the text being either the aim or the medium of all reading (as in the case of the lay father or lay brother). One will thus learn how to read, certainly, but not manuscripts alone, but also the world as our own life.

To read in the Middle Ages, or at least in the $12^{\text {th }}$ century, is thus not primarily a way to relate to a written text or Scripture [liber Scripturae], unlike the justifiable primacy of the Sacra Scriptura at the time of the Church fathers. "To read" [legere] is first to "connect" or "to reconnect" to creatures [liber creaturarum], to the world [liber mundi], to Christ [liber Christi], or to one's life in general [liber vitae] - just like one "reconnects" the different pages of a manuscript into one volume. It matters very little what one reads, or even whether one knows how to read or not, according to the Victorine's understanding. All that counts is that this "method of reading" [modus legendi] should not escape us under any circumstances, namely, this particularly human function through which one deciphers a "meaning" [sensus] behind "figures" [figurae], an "inner understanding" [intus intellegere] behind the "outward appearance" [foris speciem]: "the foolish person [insipiens] admires only their appearance," insists Hugh, "whereas the wise person [sapiens], through what he sees externally, explores the deeper intent of divine wisdom." ${ }^{\prime \prime}$ The novelty of what happens in St. Victor thus does not amount to referring to the book of nature (a theme extensively developed by Saint Augustine) or to using the visible world in order to go toward the invisible (a movement initiated by John Scot Erigena and definitively completed later by Thomas Aquinas), but to "turn nature into a second language which contributes to the edification of the human being": "every creature in the world is like a book and a picture and a mirror to us," says Alain de Lille who was a contemporary of Hugh of St. Victor, "Of our life, of our death, of our condition, of our fate, as a true symbol."' '18

In short, it suffices here simply to say it and then to prove it throughout this paper, the text of Scripture and even the written text as such is not only for Hugh of St. Victor the "medium" through which the reader passes in order to be transformed (the hermeneutics of the text), but instead the direct site of an "exposure to oneself and one's own life," through which what matters is not the relay of language, but the mute and silent way of being and living in the world (a descriptive phenomenology or a hermeneutics of

Journal of French and Francophone Philosophy | Revue de la philosophie française et de langue française

Vol XXV, No 1 (2017) | http://www.jffp.org | DOI 10.5195/jffp.2017.798 
facticity). The fool and the wise man may well have "the same book in front of their eyes" [una eademque Scriptura], concludes Hugh of St. Victor's De Tribus Diebus, but "one person notices the color or shape of the figures" [alter colorem seu formationem figurarum commendet], "whereas another praises their meaning and signification" [alter laudet sensum et significationem]. ${ }^{19}$

\section{The Art of Reading and the Art of Living}

For the Victorine, the "art of reading" [ordo legendi] will always be an "art of living" [ordo vivendi], and vice versa. This formula, with the equivalence of reading and life, does not only mean, as is often believed today when we speak of ardent readers, that opening books and turning their pages suffices to understand one's own life, or rather, that life exists first and foremost in books. Turning back to the origin of the act of reading instead of books - in so doing, the Victorine approach can enlighten us in the era of a civilization of the screen rather than of the written - the order of reading [ordo legendi] and the order of life [ordo vivendi] are the same for Hugh, in that only the "mode of reading" is something that should permeate our whole lives: it is such a clear and obvious way of deciphering the world that the letter or the text become almost superfluous - except for teaching us to decipher the signs of our own lives, or rather, for teaching us what "decoding" or "deciphering" mean. Hermeneutics is entirely a "hermeneutics of life", or of "facticity", when to live is to interpret, but without reducing interpretation to the sphere of language alone: "to the rules of study [praeceptis legendis]," says Hugh of St. Victor at the high point of the Didascalicon ("The Definition of Discipline"), "the wise man adds the rules for living [praecepta vivendi quoque] in order that the reader [lector] might know both the standard of his life [et modum vitae suae] and the nature of his study [et studii rationem]." ${ }_{20}$

In this sense, following the book's preface "to those who read" [legentibus] - which we take to mean those who learn to decipher through study or otherwise - this book "prescribes their discipline of life" [vitae suae disciplinam praescribit].2. The "order of reading" is not only an "order of life" in the Didascalicon in that respect, but probably for the first time in such an accurate and concise way in the history of philosophy, the book teaches us "what should be read" [quid legere debeat], "in what order one should read" [quo ordine legere debeat], and finally "in what manner one should read" [quomodo legere debeat].22 Whatever may be the case for the Discourse on Method, and which also shows the strength of this treatise, the Didascalicon is not primarily a "method," a "cartography" or an "encyclopedia" of knowledge. ${ }^{23}$ This book is about the "study of reading" - De Studio Legendi as the subtitle says - and thus it is also a study or an apprenticeship of life: de studio vivendi. To be convinced of this point, it suffices to see and to read, precisely in the Didascalicon, that life does not end in books but that one only learns from books what life means - in the sense of a hermeneutics of life or a

Journal of French and Francophone Philosophy | Revue de la philosophie française et de langue française 
"deciphering" that is also accessible to everyone independently from the act of reading: "Please," the Victorine implores his reader, "Spare yourself for my sake - there's only drudgery in those papers [labor est in chartis]! Go run in the open air [curre per area]!" ${ }_{24}$

It will thus have been understood. One does not first read "to understand one's life," in Hugh of St. Victor, as was the case for the Church fathers and especially for St. Augustine, who perpetually goes "from the reading of Scripture to the re-reading of his life." ${ }_{25}$ There is no question here of confession, or even conversion, but only of an "art" [ars] for which reading provides the key (deciphering), without however being the goal. Rather than "reading or rereading one's life", one "reads rather by living" according to the Victorine, or better, "one lives by reading", in that here reading becomes a way of life (the ordo legendi as an ordo vivendi). By learning to decipher in and through the text, one will gradually make "deciphering" or "interpretation" into the most routine mode of being in our life in its facticity, whether one knows how to read or not (as in the case of the lay brother): "reading [lectio]," the Didascalicon says in a definition that stands out, "consists of forming our minds upon rules and precepts [cum regulis et praeceptis informamur] taken from books [ex his quae scripta sunt]." ${ }_{26}$ To be sure, the text does serve here to support reading, and in this respect, the monastic tradition of lectio divina or daily rumination on Scripture seems to be well respected in the cloistered life of St. Victor. But by extending it here to what will later become the lectio scolastica, Hugh draws from it an "information of oneself about oneself and the world" [informamur], with respect to its rules and precepts. In other words, when the Master reads to St. Victor, he is not content merely to read, nor even to understand or to contemplate what he reads, but he strives to ensure that this reading is his reason for being a well as for living, if it is the case that the precepts of life [ordo vivendi] are identified in the same way as the prescriptions of reading [ordo legendi]. To prove this point, there is an extension of the concept of lectio, which these days has been reduced to the relation to the text but which extended in the past to the entire relation to the other. The mode of reading is precisely the act of reading themselves rather than the books themselves: "there are three types of reading," says the Didascalicon, "the teacher's [docentis], the student's [discentis], and the independent reader's [per se incipientes]. For we say, 'I am reading a book to him (the teacher)' [lego librum illi], 'I am reading the book under him (the student),' [lego librum ab illo], and 'I am reading the book' (the independent reader) [lego librum]. Order [ordo] and method [modus] are what especially deserve attention in the matter of reading." ${ }_{27}$

Journal of French and Francophone Philosophy | Revue de la philosophie française et de langue française Vol XXV, No 1 (2017) | http://www.jffp.org | DOI 10.5195/jffp.2017.798 


\section{Conclusion: The Meaning of Reading}

What is it, then, that makes the book, in the Middle Ages, and in particular in the $12^{\text {th }}$ century Renaissance that stands on the border between the lectio monastica inherited from the Church fathers and the lectio scolastica rooted in the medievals? It is not the simple rumination or muttering of the text in private [lectio monastica or lectio divina] nor the pure declaration of the text in public [lectio scolastica or a set of quaestiones], but a specific type of relation to the text [ordo legendi] which is also, and always at the same time, a specific type of relation to the other [ordo vivendi]. One does not read this or that, according to Hugh of St. Victor, but everything depends only and primarily on the "order" [ordo] and "method" [modus] by which one reads it. Reading is an "address" more than a simple "feat", including the present time which is so lacking in readers. One simply reads "a book" [lego librum] when one is a beginner, but one reads a book "of someone" [ab illo] when one becomes a student, and one reads a book "to someone" [illi] when one is appointed master: "to clarify, we should take 'reading' here in the sense of the Latin word lectio," the French commentator and editor of the Didascalicon explains, "which signifies at once 'deciphering a text', 'studying', and 'teaching'." ${ }^{28}$ As will also be the case with gestures and speech later, in a later study on The Training of Novices), the modality of the relation always creates the action for Hugh of St. Victor, and not vice versa. The Anglo-Saxon language still retains some memory of this at least when it comes to reading, since a "lecture" designates not only the fact of going through a text, but also the act of studying a passage in the context of a course and even of giving a lecture at a symposium. To return now to Hugh of St. Victor, what is important therefore to the reader who reads is not only to understand what he is reading, to which we often reduce reading today, but the correctness of the relationship to the one "to whom" and "with whom" I am read it. No reading ever takes place in the canonical life of the Victorines independently from the community which sustains it, in the communitarian structure of the $12^{\text {th }}$ century probably more than in the individual genius of the Church fathers. Abbot Gilduin, the founder of the Abbey who succeeded William of Champeaux, bears witness to this himself in his monastic rules or Liber ordinis: "no one should be seen without a book in the hand" - including even those who do not know how to read..$^{29}$

Translated by Scott Davidson

Journal of French and Francophone Philosophy | Revue de la philosophie française et de langue française Vol XXV, No 1 (2017) | http://www.jffp.org | DOI 10.5195/jffp.2017.798 
${ }^{1}$ See my Crossing the Rubicon: The Borderlands of Philosophy and Theology, trans. Reuben Shank (New York: Fordham University Press: 2016), especially Chapter 1 "Is Hermeneutics Fundamental?".

${ }^{2}$ Hugh of St. Victor, "On the Praise of Charity [De Laude caritatas]," in On Love, ed. Hugh Feiss (Hyde Park, NY: New City Press, 2012). For the works of Hugh of St. Victor, I will refer for the most part to the works available in English but will also indicate the reference in the Latin Patrology (volumes 175 and 176).

${ }^{3}$ Augustine, Confessions, XIII: 18.

${ }^{4}$ See Bochet (2004). The distance between St. Augustine and Hugh of St. Victor has already been noted by Baron (1959: 352): "one should not expect to find all of Augustine passing into the latter. One does not find in Hugh, Augustine the doctor of illumination in the theory of knowledge, Augustine doctor of grace in the doctrine of salvation, Augustine author of a conception of the temporal order from which one will derive what has been called 'political Augustinianism'."

${ }^{5}$ Roger Baron, "Rapports entre saint Augustin et Hugues de St. Victor," Revue des études augustinennes 4 (1959): 394.

${ }^{6}$ See his "Homily VII," in Book 1 of The Homilies of St. Gregory the Great on the Book of the Prophet Ezekiel, trans. Theodosia Tomkinson and Juliana Cownie (Etna, CA: Center for Traditionalist Orthodox Studies, 1990).

${ }^{7}$ Besides Crossing the Rubicon, also see my work that is rooted in the "phenomenological practice of Medieval philosophy" in God, the Flesh and the Other: From Irenaeus to Duns Scotus, trans. William Christian Hackett (Evanston, IL: Northwestern University Press, 2014): 30-34.

${ }^{8}$ Paul Ricoeur, The Conflict of Interpretations, ed. Don Ihde (Evanston, IL: Northwestern University Press, 1974): 6, 11.

9 Dominique Janicaud, Phenomenology “Wide Open," trans. Charles N. Cabral (New York: Fordham University Press, 2005): 48, 50.

${ }^{10}$ St. Bonaventure, Collations on the Six Days, trans. Jose de Vinck, in Works of Bonaventure 5 (Quincy, Mass.: Franciscan Press, 1995), bk. XIII, ch. 12, v. 390. See also my commentary "Reading the Book," in God, the Flesh and the Other: From Irenaeus to Duns Scotus.

${ }^{11}$ See Emmanuel Falque, Le combat amoureuse (Paris: Hermann, 2014): 325-341.

${ }^{12}$ Hugh of St. Victor, On the Three Days [De tribus diebus], in Trinity and Creation: A Selection of Works of Hugh, Richard, and Adam of St Victor, eds. Boyd Taylor Coolman and Dale M. Coulter (Hyde Park, NY: New City Press, 2011), 63. Also cited in St. Bonaventure, Works of St. Bonaventure: Breviloquium, ed. Robert J. Karris, trans Dominic V Monti (St. Bonaventure, NY: Franciscan Institute Publications, 2005).

${ }^{13}$ Jean Decorte, “L'art de lire au Moyen Age," in Le vaste monde à livres ouverts (Brugge: Lannoo, 2002), 95.

${ }^{14}$ Hugh of St. Victor, On the Three Days [De tribus diebus], 63-4.

${ }^{15}$ Ivan Illich, In the Vineyard of the Text (Chicago: The University of Chicago Press, 1993), 60.

Journal of French and Francophone Philosophy | Revue de la philosophie française et de langue française Vol XXV, No 1 (2017) | http://www.jffp.org | DOI 10.5195/jffp.2017.798 
${ }^{16}$ Dom Jean Leclercq, The Love of Learning and the Desire for God: A Study of Monastic Culture, trans. Catharine Misrahi (New York: Fordham University Press, 1961), 73.

${ }^{17}$ Hugh of St. Victor, On the Three Days [De tribus diebus], 64.

${ }^{18}$ Alain de Lille, "Omnis mundi creatura," a poem cited and translated by G. Dahan, "L'occident médiéval lecteur de l'écriture," Cahiers Evangile vol. 116: 60. We also borrow from this poem the formula of nature as a "second language".

${ }^{19}$ Hugh of St. Victor, On the Three Days [De tribus diebus], 64.

${ }^{20}$ Jerome Taylor, ed. The Didascalicon of Hugh of St. Victor (New York: Columbia University Press, 1961), Book III, Ch. 12, 94 (trans. mod.).

${ }^{21}$ Taylor, The Didascalicon of Hugh of St. Victor, 44.

${ }^{22}$ Taylor, The Didascalicon of Hugh of St. Victor, 44.

${ }^{23}$ Luce Giard, "Hugues de St. Victor: cartographe du savoir" in L'abbaye parisienne de St. Victor au Moyen-Age, ed. Jean Longère (Paris-Turnhout: Brepols, 1991), 253-269. One will note however the true theological aim of such a cartography that is highlighted by the author and to which we will return (see p. 258).

${ }^{24}$ Taylor, The Didascalicon of St. Victor, III, 7, 91.

${ }^{25}$ Isabelle Bochet, Le firmament de L'Ecriture: L'herméneutique augustinenne (Paris: Etudes augustiniennes, 2004): 157-327.

${ }^{26}$ Jerome Taylor, ed. The Didascalicon of Hugh of St. Victor (New York: Columbia University Press, 1961): III, 7, 19.

${ }^{27}$ Ibid.

${ }^{28}$ Michel Lemoine, Introduction au Didascalicon (Paris: Cerf, 1991): 19.

${ }^{29}$ Gilduin was the second abbey of the order under the jurisdiction of which Hugh taught, Liber ordinis. This expression is reported by Roger Baron in Hugues et Richard de St. Victor (Bruxelles: Bloud et Gay, 1961): 13. 